\title{
Permanent Disability between Current Medicolegal System and Reality (A Retrospective Study in Menoufya Medicolegal Authority, Egypt)
}

\author{
Mohamed Ahmed Hwait, ${ }^{1}$ Magda Mokhtar Ramadan, Ayman Mohamed Abd Elfatah ${ }^{2}$ \\ ${ }^{1}$ Medico-Legal Authority-Ministry of Justice, Egypt. \\ ${ }^{2}$ Forensic Medicine and Clinical Toxicology Department, Ain shams University, Egypt.
}

\begin{abstract}
Introduction: Disability is simply the inability to engage in any substantial gainful activity as a result of any physical or mental impairment. Disability, impairment and infirmity are interchangeable terms. It is always difficult and confusing to distinguish between these terms. Disabilities and permanent infirmity have a great impact on most of the societies. They represent a challenging health, social and medicolegal wide world problem. Around $15 \%$ of the world's population, or estimated 1 billion people, live with disabilities. According to 2006 Egyptian census, it was estimated that $1.8 \%$ of the Egyptian population is living with disabilities and the number increase as $10.7 \%$ of the Egyptian population is living with disabilities according to 2017 Egyptian census.

Aim of the Work: To assess the validity and effectiveness of laws and tables determining disability percentage and compare between Egyptian permanent infirmity tables and other methods like ICF

Methods: A retrospective study of all cases with permanent infirmity prescribed to Menoufya Medicolegal Authority for 6 months period starting from $1^{\text {st }}$ of July 2015 till the $31^{\text {th }}$ of December.

Results: The total cases of injuries with permanent infirmity were 295 of which 205 were excluded as some of these cases were not considered as disabilities according to the Egyptian permanent infirmity tables e.g. skin distortion, so only 90 cases (30.5\%) were enrolled in the study. The highest percent was in age group between 30-45 years old (42.2\%) and the least in age group between 1530 years old (4.4\%). Male cases were the predominant represented (74 cases, $82.2 \%)$ blunt instruments were accountable for (55 cases, $61.1 \%$ ) followed by sharp instruments (18 cases, 20\%). Skeletal disabilities were the predominant (48 cases, 53.4\%) followed by peripheral nerve affection (13 cases, $14.4 \%$ ). The cause of disability was mostly due to non-occupational injuries (84 cases, 93.3\%), which occurred as a sequence of homicidal manner (68 cases, $81 \%$ ) while there were no suicidal cases that ended in permanent infirmities.

Conclusion: The Egyptian permanent infirmity tables are in need for reupdating and fulfillment of the missing infirmities.

Recommendations: Applying ICF as a tool for disability assessment guarantees amore fair compensation method. A large study on disability assessment in Egypt should be carried out to cover all governorates and include, not only entities of the Medicolegal Authority but also those of the Health Insurance Organization ,being the other party involved in this critical risk with applying ICF as a tool for infirmity assessment

Key words $\quad$ ICF: International Classification of Function, Disability and Health; EPI: Egyptian permanent infirmity tables.
\end{abstract}

\section{Introduction}

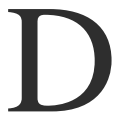
isability is simply the inability to engage in any substantial gainful activity as a result of any physical or mental impairment which has lasted or can be expected to last for a continuous period not less than 12 months (Ghaleb et al., 2018). Disability, impairment and infirmity are interchangeable terms. It is always difficult and confusing to distinguish between these terms when it comes to description and evaluation (World Health Organization [WHO], 2011).

Legal concern with permanent infirmity began since law 1937 with law code 58. Amendments of this law was carried out on Egyptian Penal Code 2003.According 
to the Egyptian Penal Code of 2003 article 240 of the criminal law, permanent infirmity is defined as "the permanent and incurable loss of an organ or its function either partially or totally" (Egyptian Penal Code, 2003).

Disabilities and permanent infirmity have a great impact on most of the societies. They represent a challenging health, social and medicolegal wide world problem (Cocchiarella, 2018). Around 15\% of the world's population, or estimated 1 billion people, live with disabilities. They represent the world's largest minority (World Health Organization [WHO], 2011). Accurate reports about the cases of disability in Egypt are missing. According to 2006 Egyptian census, it was estimated that $1.8 \%$ of the Egyptian population is living with disabilities (El-Saadani and Metwally, 2019). The United Nations estimates a much higher figure, that 12 million people are living with some type of disability (World Health Organization [WHO], 2011). The Egyptian census 2017 revealed that $10.7 \%$ of the Egyptian population is living with disabilities (State Information Service [SIS], 2017). Injuries leading to disabilities in Egypt are due either to road traffic (RTA), other accidents, violence or workplace injuries (Shokry, 2016).

Disabilities have a great impact on the various aspects of life. They can affect and modulate the details and style of a person's attitude and behaviors and outcomes (María, et al., 2016).

Disabilities usually result as a consequence of diseases or injuries (World Health Organization [WHO], 2011).

There are many classifications of types of disabilities e.g. according to the affected systems, extent or persistence of disabilities.

Evaluation of permanent disability is an appraisal of the nature and extent of the patient's illness or injury as it affects his personal efficiency in daily life activity (Causey et al., 2008). It is carried out through medical evaluation of the condition. This is performed by a physician, using standard methods as outlined in the guides to determine the degree of the disability (Carl et al., 1987). It could be performed by the treating physician or by an independent medical examiner who evaluates but doesn't provide care for an individual (Nolo, 2018). A wide range of variable schedules of disability evaluation is present all over the world. They show similarities in some items of evaluation and difference in others (Harwood et al., 2008).

Disability should not be considered permanent until the clinical findings indicate that the medical condition is static and well stabilized, often termed the date of maximal medical improvement (MMI). In other words, it refers to a date from which further recovery or deterioration is not anticipated, although over time there may be some expected change. Once an impairment has reached MMI, a permanent disability rating could be performed (Ingerman and Horwitz, 2018).

In Egypt, injured cases of violence, RTA and other accidents are referred to medicolegal experts of the Ministry of Justice to trace the healing process until reaching MMI to assess the disability percentage. Injured cases due to workplace accidents are referred to the Medical Insurance Ministry of Health for further follow up and assessment of disability. Sometimes when a victim complains about the percentage issued or the court looks for another expert opinion, the court refer these cases to the Medicolegal Authority -Ministry of Justice (Shokry, 2016).

According to Hassan (2020) certain procedures are followed to ascertain and evaluate disability by Egyptian Medicolegal Authority

These include the following:

1. Collection of circumstantial data

2. Collection of clinical data

3. Medicolegal report

4. Disability rating report

The percentage of disability is calculated according to table no. 2 of social insurance law no. $79 / 1975$ and its amendment by law no. 25/1977. This is applied to all cases of injury whether accidental (due to road traffic or workplace accidents) or criminal. This law allocates a precise percentage for each injury, and the total percentage of disabilities is the sum of the individual disability percentage.

Forensic pathologists are facing many Challenges and problems on evaluating disability.

Malingering is one of the most prevalent challenge (Heilbronner et al., 2009). Lack of standard of evidence and methods (e.g. no assessment tools for the certificate of some symptoms (e.g. pain, limitation of joint movement) (Donceel et al., 2008). Also Lack of update of the Egyptian permanent infirmity evaluation tables. Schedules used in Egypt for permanent infirmity evaluation are very old. These schedules are the tables submitted by Abbas Helmi Rabie vice of medicolegal physician in 1958 (Carl et al., 1987).

ICF is simply a classification of health and disability which emphasizes environmental factors in creating disability. It has been developed by the World Health Organization and approved in May 2001. It provides a unified and standard language and a framework for the description of health and health related state (Ferreira et al., 2014).

According to Kostanjsek (2011), ICF describes functioning at three perspectives: body, person and societal. It organizes information in two parts. The first part deals with functioning and disability, the second part covers contextual factors.

Component of the 1st part (functioning and disability) are divided in:

1. Both components including body functions and anatomical structures. A problem in these components is noticed as impairment (Finger et al., 2012).

2. Activity and participation

According to Vandervelde et al. (2007), activity is the execution of a task or action by individual and participation is the involvement in a life situation. A difficulty at the person level would be noted as activity limitation and at the societal level as participation restriction. 


\section{Aim of the Work}

To assess the validity and effectiveness of laws and tables determining disability percentage and compare between Egyptian permanent infirmity tables and other methods like ICF.

This is achieved through assessment of the cases of disabilities and their files presented to Menoufya Medicolegal Authority. Reassessment of the disability percentage of these cases will be done according to ICF.

\section{Materials and methods}

The current study is a retrospective study that included examination of the records of all cases with permanent infirmity presented to the Menoufya Medicolegal Authority to assess permanent infirmity during 6 months period starting from 1st of July 2015 till the 31st of December 2015. A total number of 295 cases was presented during this period, of which 205 were excluded. This was because injuries of some of these cases were not considered as disabilities according to the Egyptian Permanent infirmity tables e.g. skin distortion, psychological and psychiatric disorders and temporary disabilities, and other cases did not return for further evaluation. Accordingly, only 90 cases were enrolled in the present study. A data sheet was prepared to fulfill the requirements of the protocol of this study.

The presence of an infirmity is confirmed after reaching the maximum medical improvement (MMI) and the percentage of the settled disability was then evaluated according to EPI.

Reassessment by applying ICF checklist was carried out upon those cases.

\section{Ethical Considerations}

Permission had been taken from the director of the Menoufya Medicolegal Authority. The approval of the local research ethics committee, Faculty of Medicine, Ain Shams University had been obtained. All personal data had been kept anonymous to ensure confidentiality of data.

The collected data were tabulated and statistically analyzed using IBM SPSS Statistics version 20.

\section{Results}

Table (1) and figure (1) show that the highest number of cases was in the age group between 30 and 45 years old (38 cases, 42.2\%). Cases of age group between 0-15 years old were the least (4 cases, $4.4 \%$ ).
Table (2) and figure (2) show that number of males were significantly exceeding that of the female cases (74 cases, $82.2 \%$ and 16 cases, $17.8 \%$ respectively).

Table (3) show that males were more exposed to permanent infirmity at the different age groups except for age group between 0-15 years old where both genders were equally affected.

Table (4) and figure (3) show that most of the cases were manual workers (44 cases, $48.9 \%$ ) while the least cases were merchants ( 3 cases, $3.3 \%$ ).

Table (5), and figure (4) show that blunt instruments were accountable for inflicting injuries and disabilities in most of the cases (55 cases, $61.1 \%$ ), while heat was responsible about injury of only one case (1.1\%).

Table (6) and figure (5) show that contused injuries were the predominant (55 cases, 61.1\%). While burn (1 case,1.1\%).

Table (7) and figure (6) show that the predominant type of disabilities were skeletal impairments, (48 cases, 53.3\%) while Loss of internal organs and sexual organs affection presented in 1case (1.1\%) each.

Table $(8,9)$ show that non-occupational injuries were the predominant cause of disabilities (84 case,93.3\%), while occupational injuries resulted in disabilities of only 6 cases (6.7\%). Homicidal or intentional manner with use of violence was the predominant (68 cases, percentage $81 \%$ ) while less cases were due to accidents (16 cases, 19\%). Suicidal injuries were not reported.

Table (10) and figure (7) show that disabilities that related to the brain and spinal cord affection got the highest assessment percentage while aural impairment got the lowest assessment percentage regardless the method of assessment.

Table (11) shows that assessment of disability using ICF on the cases of this study which were previously assessed according to the EPI tables got higher disability percentage at both initial and follow up assessment.

Table (1): Age percentage distribution among cases included in the study

\begin{tabular}{|c|c|c|}
\hline Age & Number & Percentage\% \\
\hline $0-15$ years & 4 & 4.4 \\
\hline 15-30 years & 27 & 30.0 \\
\hline $30-45$ years & 38 & 42.2 \\
\hline 45-60 years & 11 & 12.2 \\
\hline$>60$ years & 10 & 11.2 \\
\hline Total & 90 & 100.0 \\
\hline
\end{tabular}


Table (2): Gender percentage distribution of gender among cases included in the study

\begin{tabular}{|c|c|c|}
\hline Gender & Number & Percentage\% \\
\hline Male & 74 & 82.2 \\
\hline Female & 16 & 17.8 \\
\hline Total & 90 & 100.0 \\
\hline
\end{tabular}

Table (3): Percentage distribution of gender for each age group in the study

\begin{tabular}{|c|c|c|c|c|}
\hline & & \multicolumn{3}{|c|}{ Total number } \\
\hline & & male & female & \\
\hline \multirow{5}{*}{ Age group } & 0-15 years & 2 & 2 & 4 \\
\hline & $15-30$ years & 22 & 5 & 27 \\
\hline & 30-45 years & 32 & 6 & 38 \\
\hline & 45-60 years & 10 & 1 & 11 \\
\hline & $>60$ years & 8 & 2 & 10 \\
\hline \multicolumn{2}{|c|}{ Total } & 74 & 16 & 90 \\
\hline
\end{tabular}

Table (4): Occupation percentage distribution among cases included in the study

\begin{tabular}{|c|c|c|}
\hline Occupation & Number & Percentage $\%$ \\
\hline Manual workers & 44 & 48.9 \\
\hline Students & 14 & 15.6 \\
\hline Farmers & 12 & 13.3 \\
\hline Housewives & 10 & 7.8 \\
\hline Professionals & 7 & 3.3 \\
\hline Merchants & 3 & 100.0 \\
\hline Total & 90 & \\
\hline
\end{tabular}

Table (5): Percentage distribution of types of the causative instruments accountable for inflicted injuries among cases included in the study.

\begin{tabular}{|c|c|c|}
\hline Type of instrument & Number & Percentage\% \\
\hline Blunt & 55 & 61.1 \\
\hline Sharp & 18 & 20 \\
\hline Firearms & 14 & 15.6 \\
\hline Combined & 2 & 2.2 \\
\hline Heat & 1 & 1.1 \\
\hline Total & 90 & 100.0 \\
\hline
\end{tabular}

Table (6): Distribution frequency of types of injuries among cases included in the study

\begin{tabular}{|c|c|c|}
\hline Type of injury & Number & Percentage\% \\
\hline Contused & 55 & 17.1 \\
\hline Cut & 16 & 15.6 \\
\hline Firearm & 14 & 2.2 \\
\hline Mixed injuries & 2 & 2.2 \\
\hline cut contused & 2 & 1.1 \\
\hline Burn & 1 & 100.0 \\
\hline Total & 90 & \\
\hline
\end{tabular}


Table (7): Percentage distribution of types of disability among the cases included in the study

\begin{tabular}{|c|c|c|}
\hline Types of disability & Number & Percentage\% \\
\hline Skeletal impairment & 48 & 53.4 \\
\hline Peripheral nerves affection & 13 & 14.4 \\
\hline Ocular impairment & 8 & 8.9 \\
\hline Mixed & 8 & 8.9 \\
\hline Brain and spinal cord affection & 7 & 7.8 \\
\hline Mechanical and motor impairment & 2 & 2.2 \\
\hline Aural impairment & 2 & 2.2 \\
\hline Sexual organs impairment & 1 & 1.1 \\
\hline Loss of internal organ & 1 & 1.1 \\
\hline Total & 90 & 100.0 \\
\hline
\end{tabular}

Table (8): Percentage of context of disabilities among the cases included in the study

\begin{tabular}{|c|c|c|}
\hline Cases & Number & Percentage\% \\
\hline Non-occupational & 84 & 93.3 \\
\hline Occupational & 6 & 6.7 \\
\hline Total cases & 90 & 100.0 \\
\hline
\end{tabular}

Table (9): The manner of non-occupational disabilities among the cases included in the study

\begin{tabular}{|c|c|c|}
\hline Manner & Number & Percentage\% \\
\hline Homicidal & 68 & 81 \\
\hline Accidental & 16 & 19 \\
\hline Total cases & 84 & 100.0 \\
\hline
\end{tabular}

Table (10): Average disability percentage per each type of disability, using different methods of assessment.

\begin{tabular}{|c|c|c|c|c|}
\hline Type of disability & Number of cases & Average EPI initial & Average EPI follow-up & Average ICF \\
\hline Skeletal impairment & 48 & $19.3 \%$ & $26.2 \%$ & $32.1 \%$ \\
\hline Loss of internal organ & 1 & $30.0 \%$ & $30.0 \%$ & $30.0 \%$ \\
\hline Ocular impairment & 8 & $52.8 \%$ & $52.9 \%$ & $56.6 \%$ \\
\hline Brain and spinal cord affection & 7 & $65.7 \%$ & $95.7 \%$ & $89.9 \%$ \\
\hline Peripheral nerves affection & 13 & $25.3 \%$ & $41.5 \%$ & $48.6 \%$ \\
\hline Sexual organs impairment & 1 & $25.0 \%$ & $25.0 \%$ & $35.0 \%$ \\
\hline Aural impairment & 2 & $12.5 \%$ & $12.5 \%$ & $13.5 \%$ \\
\hline Mechanical and motor impairment & 2 & $46.0 \%$ & $55.0 \%$ & $58.5 \%$ \\
\hline Mixed & 8 & $56.5 \%$ & $70.0 \%$ & $73.8 \%$ \\
\hline
\end{tabular}

Table (11): Paired Samples Test correlating disabilities assessment using ICF and Egyptian Permanent Infirmity at both initial and follow-up assessments.

\begin{tabular}{|c|c|c|c|c|c|c|c|c|}
\hline & \multicolumn{5}{|c|}{ Paired Differences } & \multirow{3}{*}{$\mathrm{t}$} & \multirow{3}{*}{ df } & \multirow{3}{*}{$\begin{array}{l}\text { Sig.(2- } \\
\text { tailed) }\end{array}$} \\
\hline & \multirow{2}{*}{ Mean } & \multirow{2}{*}{ SD } & \multirow{2}{*}{ SD. Error Mean } & \multicolumn{2}{|c|}{$\begin{array}{l}\text { 95\% confidence interval of the } \\
\text { difference }\end{array}$} & & & \\
\hline & & & & Lower & Upper & & & \\
\hline $\begin{array}{l}\text { ICF vs. EPI } \\
\text { Initial }\end{array}$ & .14 & .18 & .019 & .10 & 18 & 7.5 & 89 & .000 \\
\hline $\begin{array}{l}\text { ICF vs. EPI } \\
\text { Follow-up }\end{array}$ & .04 & .12 & .012 & .02 & .07 & 3.6 & 89 & .001 \\
\hline
\end{tabular}




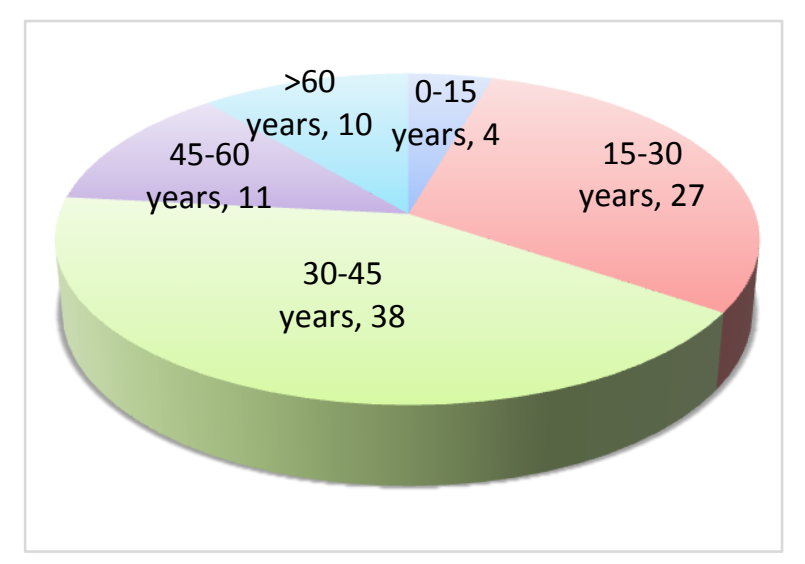

Figure (1): Pie chart showing age distribution among cases included in the study

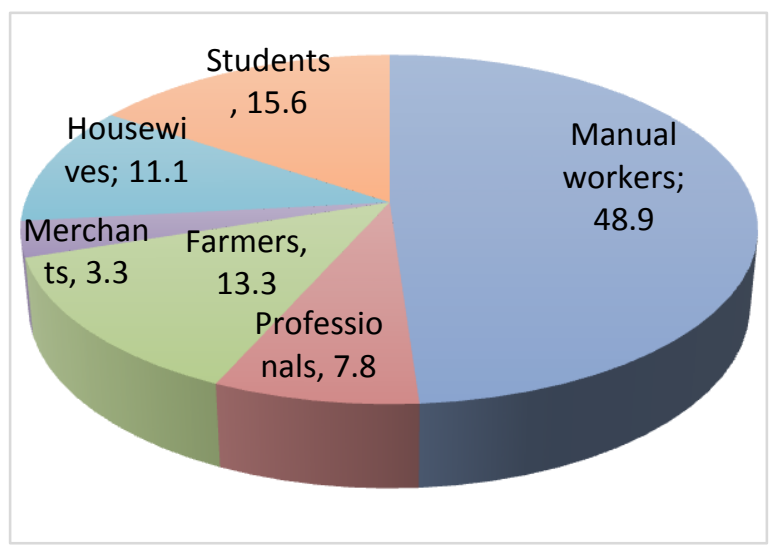

Figure (3): Pie chart showing occupation distribution among cases included in the study

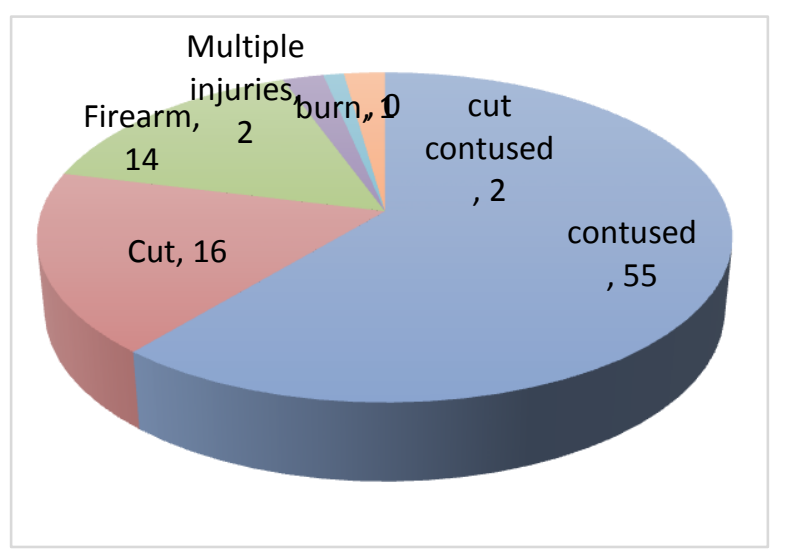

Figure (5): Pie chart showing distribution of types of injuries among cases included in the study

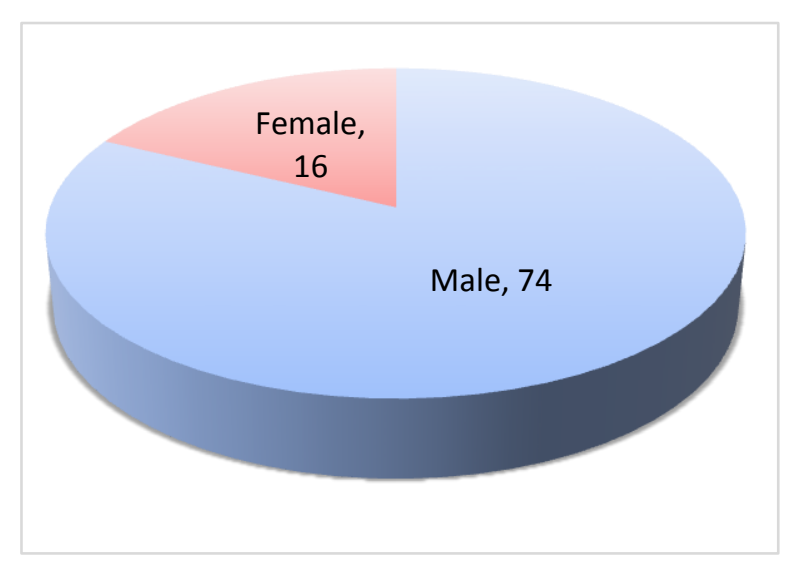

Figure (2): Pie chart showing gender distribution among cases included in the study

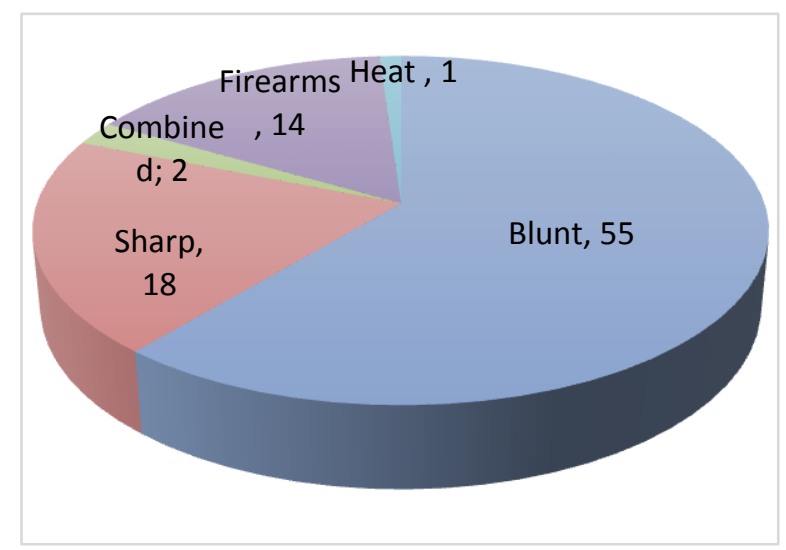

Figure (4): Pie chart showing types of the causative instruments accountable for the inflicted injuries among cases included in the study.

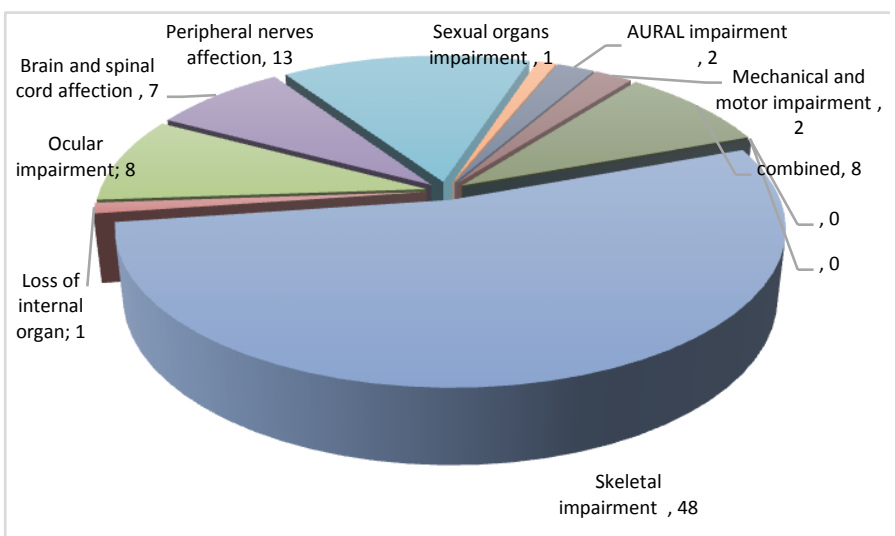

Figure (6): Pie chart showing the distribution of types of disability among the cases included in the study 


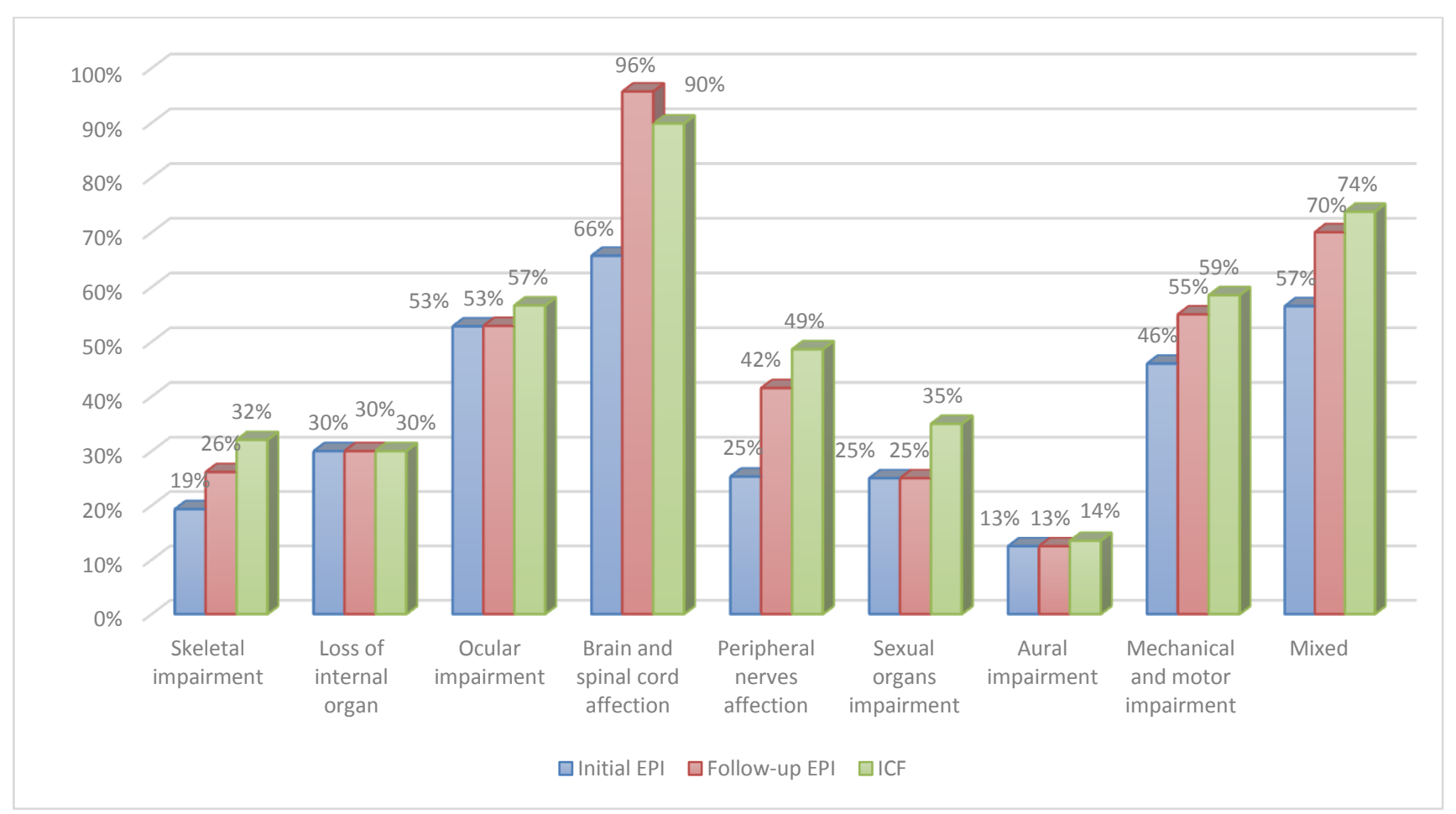

Figure (7): Average disability percentage in each type of disability according to both EPI and ICF.

\section{Discussion}

Permanent infirmity is defined as "functional limitation caused by a physical or mental impairment that restricts the ability of a person to perform the daily activities, and that infirmity is expected to remain with the person for the person's expected natural life". Medico-legal infirmities are defined as "unintended injury or complication that results in disability at the time of discharge, death or prolonged hospital stay and that is caused by health care management rather than by the patient's underlying disease processes (Ghaleb, et al., 2018).

The results of this work in studying the cases had shown that the highest number of disabled individuals was in the age group between 30 and 45 years old followed by age groups between 15 and 30 years old and 45-60 years, then age group over 60 years old. Cases of age group between 0-15 years old were the least. These results agree to some extent with results of the study of Abd El-Hady et al. (2013) which declared that the highest percent of permanent disability was in age group 20-30 followed by age group 30-40 years. The least percent was in age group 0-10. These findings can be explained by the fact that the age between 15 and 45 years is the age of maximum activity where persons are engaged in labor market especially physically demanding occupations. Also, they are more liable to violence and accidents (Martino and Chappell, 2006).

On contrary, the results of the present study disagree with World Health Organization (WHO), 2009) report which detected that highest prevalence rate of disability was in age group over 60 years. This could be attributed to the fact that developed countries have much aging population in comparison to the Egyptian society. Developed countries as Japan, 26.3\% of its population being 65 years of age or older (United Nations (UN), 2015).

The current study revealed that disabilities were significantly predominant in males than females. These results are in accordance with many studies: Abd El-Hady et al. (2013), Wasfy et al. (2009) and Collins (1991) reported similar findings. This may be explained by the fact that men are dominating the labor market in developing countries, especially the risky ones. Also, they are more liable to injuries and violence (Carol, 2007).

On the other hand, opposing results declared by World Health Organization (WHO), 2009), showed prevalence rates in males equivalent to females in higher income countries. Furthermore, females were higher than males in lower income countries (World Health Organization (WHO), 2011).

The current study showed that there was no significant correlation between age and gender. This means that there was no significant difference between age groups regarding gender as male gender is dominant in all groups. This agrees with the similar findings of Kirsten (2004). Thus, the degree of liability for those who had permanent disability in each age group was similar for both women and men as they face same events and same difficulties and hazards. The cases enrolled in the present study were legal cases that presented to medicolegal authority.

The current study revealed that most of the cases were manual workers (44 cases, $48.9 \%$ ) followed 
by students ( 14 cases, $15.6 \%)$, farmers (12 cases, $13.3 \%)$, housewives (10 cases, $11.1 \%$ ), professionals ( 7 cases, $7.8 \%$ ), then finally merchants (3 cases, 3.3\%).Similar findings were obtained by Cruz (2017) reported highest percent of injuries and fatalities among manual workers.

This can be explained according to Badawy et al., (2011), who stated that manual workers face in their works more hazards and risk of injury than other categories.

On contrary to our results, Abd El-Hady et al. (2013) found in their study that the greatest percentage of permanent infirmity was among farmers. This can be explained by the fact that the cases of their study were from rural areas where farmers represented the majority of the population.

The current study revealed that most of the studied cases were injured by blunt instruments (55 cases, $61.1 \%$ ), followed by sharp instruments (18 cases, $20 \%$ ), then firearms (14 cases, 15.6\%). Combined types of instruments caused injuries in 2 cases (2.2\%) while heat caused the injury in one case (1.1\%).

These findings coincide with most of the studies which ranked blunt instruments as the first cause of injuries whether in accidental, intentional or occupational injurie (Simon et al., 2019).

Abd El-Hady et al. (2013), Shalabi et al. (2006) and Zanaty (2005) reported that blunt instruments were the most common instrument precipitating in injuries that lead to permanent disability, followed by sharp instruments.

Cruz (2017) said that falls from height continue to be a common injury risk among construction occupational injuries.

Preponderance of blunt instruments over sharp instruments may be because the later are prohibited by law and hence are less frequently carried (Girgis et al., 2017).

Opposing to our results, Cemalovic et al. (2016) said that the most common injuries among workers were the ones inflicted by sharp objects.

Firearms have been reported to be the most common cause of CNS and spinal cord injuries ended with disabilities in the USA, Brazil, Soweto, South Africa. They showed that $33 \%$ of respondents have a gun in their home or garage; of these, $22 \%$ are gun owners themselves and $11 \%$ live in an environment with a gun present (Nelson et al., 1989).

This discrepancy could be attributed to the stringent control over firearms and sharp instruments in Egypt.

The current study revealed that most cases with permanent infirmity were due to contused injuries (55 cases, $61.1 \%$ ) followed by cut injuries (16 cases, $17.8 \%$ ), firearm injuries (14 cases, 15.6\%), mixed injuries (2 cases, $2.2 \%$ ), cut contused injuries (2 cases, $2.2 \%$ ) and finally burn (1 case, 1.1\%).The obtained results in the current study go hand in hand with those declared by Nicholas ( 2016), where blunt injuries were the most common popular injuries. Whereas other forms of injuries (e.g., gunshot wounds, sharp force injuries) occurred under a relatively limited number of circumstances. In contrast to the present study, firearm injuries have been reported to be the most common cause of CNS disabilities in Brazil, South Africa with a high prevalence of spinal cord injuries ended with permanent disabilities (Cock, 1989). This could be attributed to the legal allowance of firearms in these countries. In Egypt carrying firearms is aggressively prohibited and considered a crime by law and to a lesser extent caring sharp instrument (World Health Organization (WHO), 2015).

The current study showed that, skeletal impairments were the most predominant type of disability followed by peripheral nerve affection, ocular impairment, mixed types and brain and spinal cord affection. Aural impairment and mechanical and motor impairment found in a lesser number of cases. The least were loss of internal organs and sexual organs affection. These results coincide to a great extent with those declared by World Health Organization (WHO, 2011) which showed that skeletal disability was the predominant disability followed by ocular disability, aural disability, brain and spinal cord affection, mechanical and motor impairment.

The present study showed that most of injuries were due to non-occupational causes (84 cases, 93.3\%), while few cases were in occupational context (6 cases, $6.7 \%)$.

Despite the aforementioned facts, the cases of disabilities in the present study due to accidental causes were lower than cases of homicidal causes. This explained by the fact that most of these cases were unreported or treated as civil cases which represented to other parties e.g. insurance physicians not to the medicolegal authority (Shokry, 2016).

Takala et al. (2007) had emphasized that occupational accidents in general especially in many developing and newly industrialized countries were underreported.

Non-occupational injuries in the present study were mostly homicidal (68cases, 81\%), the remaining were accidental (16cases, 19\%). Suicidal injuries were not reported. The obtained results in the current study totally agree with those of Abd El-Hady et al. (2013), who found that criminal assaults lead to the highest cases of infirmities, followed by accidental injuries. This could be attributed to the increased life stresses and act of violence such as youth violence or intimate partner violence leading to increase criminal and violence tendencies (World Health Organization (WHO), 2011).

In Egypt, road traffic accidents (RTA) are growing each year. This because of the rapid increase in number of the vehicles on the roads in addition to the lack of proper strategy for prevention of these accidents (Ghaleb, et al., 2018).

The results of this study revealed significant correlation between disability assessment and type of disability regardless the method of assessment. The 
highest percentage of disability was found in brain and spinal cord affection followed by ocular and mixed impairment. The lowest percentage of disability was aural impairment.

These findings are in accordance with some extent with Alghnam, et al. (2017) and Whiteneck, et al. (2016) reported that head and brain injuries are very dangerous injuries. About $1 / 3$ of the patients with head injuries who were treated of traumatic head injury suffer severe permanent disabilities due to the neurological insults.

Applying ICF on the cases of this study at both initial and follow up assessment revealed significant higher disability percentage than that was recorded on applying the EPI assessments for all types of disabilities.

Leonardi et al., (2013) emphasized that implanting the ICF would give a new approach to disability, makes it possible to better address and assess the needs of disabled persons.

This variation in disability evaluation on applying ICF and EPI tables on the study cases could be explained by the fact that ICF depends on health condition, impairment, functional limitation and personal and environmental factors. The main ICF scope is to describe disability and functioning i.e. functional status of the patient as a whole. EPI tables take in consideration body functions and body structures (Centers for Disease Control and Prevention (CDC), 2009). Thus, applying ICF guarantees greater and more fair compensation to the patients.

\section{Conclusion}

The Egyptian permanent infirmity tables are in need for reupdating and fulfillment of the missing infirmities.

\section{Recommendations}

Applying ICF as a tool for disability assessment guarantees amore fair compensation method. A large study on disability assessment in Egypt should be carried out to cover all governorates and include, not only entities of the Medicolegal Authority but also those of the Health Insurance Organization ,being the other party involved in this critical risk with applying ICF as a tool for infirmity assessment

\section{References}

Abd El-Hady R, Thabet H and Ghandour N (2013): Medico-Legal Aspects of Permanent Infirmities as a Sequel of Different Types of Injuries. Ain Shams Journal of Forensic Medicine and Clinical Toxicology, 20(1), 92-98.

Alghnam S., AlSayyari A., Albabtain I. and Aldeba B., (2017): Long-term disabilities after traumatic head injury (THI): a retrospective analysis from a large level-I trauma center in Saudi Arabia. Injury Epidemiology Journal,4(1):29.

Badawy S., Girgis N., Al-Fiky A. and Mabro H., (2011): Clinical study of some medico-legal aspects of cases with extremities trauma admitted to
Menoufia University Hospital over 1 year (2011), Menoufia Medical Journal, 197(33):67-196.

Carl B., Tolson M. and Copes W., (1987): Evaluating trauma care. Journal of Trauma, 27(4):370-377.

Carol V., (2007): Gender difference in determinants and consequences of health and illness. Journal of Health, Population and Nutrition, 25(1):47-61.

Causey J., McFarren T. and Nimlos J., (2008): The AMA 6th: Accelerating the Demise of Permanent Disability in Workers' Compensation, IAIABC Journal, 45(1):49-64.

Centers for Disease Control and Prevention (CDC, 2009): Prevalence and Most Common Causes of Disability Among Adults. Available at: http://www.cdc.gov/mmwr/preview/mmwrhtml/ mm5816a2.htm

Cemalovic N., Rosic S. and Toromanovic N., (2016): Analysis of the causes of occupational injuries and application of preventive measures. Journal of the Academy of Medical science of Bosnia and Herzegovina, 28(1):51-52.

Cocchiarella L., (2018): Disability assessment and determination in the United States. American Medical Association. [Online] Available at: https://www.uptodate.com. [Accessed 15 ${ }^{\text {th }}$ December 2019].

Cock J., (1989): Hidden consequences of state violence: spinal cord injuries in Soweto, South Africa. Social Science \& Medicine Journal, 29(10):1147-1155.

Collins J. and Biddlecom A., (1991): Impairments due to injuries. American Journal of Public Health (AJPH), 81(12):1670-1672.

Cruz J., (2017): A review of electrical burns admitted in a Philippine Tertiary Hospital Burn Center. Burns open Journal, 1(1):20-24.

Donceel P., Brage S., RUS M. and boer W., (2008): Medico-legal reasoning in disability assessment: A focus group and validation study. BMC Public Health. [Online] Available at: https://www. bmcpublichealth. biomedcentral. com. [Accessed 15 ${ }^{\text {th }}$ March 2016].

Egyptian Penal Code (2003): Article 240. Cairo: Egyptian Government. [Online] Available at: https://www.refworld.org [Accessed15th March 2018].

El-Saadani S. and Metwally S., (2019): The quality of life of youth with disabilities in Egypt with special focus on educational achievement. The Economic Research Forum (ERF). [Online] Available at: https://www.erf.org.eg. [Accessed $15^{\text {th }}$ March 2020].

Ferreira M., Alves S. and Maia M., (2014): The use of the International Classification of Functioning, Disability and Health, version for Children and Youth (ICF-CY), in Portuguese special education assessment and eligibility procedures: The professionals' perceptions. European Journal of Special Needs Education, 29(3):327-343. 
Finger M., Escorpizo R., Glässel A. and Gmünder H., (2012): ICF Core Set for vocational rehabilitation: results of an international consensus conference. Disability and Rehabilitation Journal, 34(5): 429-438.

Ghaleb S., Hassan D., Shehab M. and Hassan S., (2018): Medico-legal aspects of disabilities due to orthopedic injuries and compensations in Egypt. Journal of Forensic and Legal Medicine, 58(1): 34-40.

Girgis N., Zanaty A., El Agmy S. and Soha A., (2017): Patterns of facial trauma in menoufia university hospital. Menoufia Medical Journal, 30(4):11861192.

Harwood R., Rogers A. and Dickinson E., (2008): Measuring handicap: the London handicap scale, a new outcome measure for chronic disease. Journal of health care, 3(1): 11-16.

Hassan A., (2020): Personal contact with manager of Egyptian Medicolegal Authority

Heilbronner R., Sweet J., Morgan J. and Larrabee G., (2009): American Academy of Clinical Neuropsychology Consensus Conference Statement on the neuropsychological assessment of effort, response bias, and malingering. The Clinical Neuropsychologist journal, 23(7):1093-1129.

Ingerman and Horwitz (2018): Maximum Medical Improvement. [Online]Available at: https://www.ihlaw.com. [Accessed $16^{\text {th }}$ December 2019].

Kirsten N., (2004): Gender differences in physical disability among an elderly cohort. Journal of Public Health, 94(8): 1406-1411.

Kostanjsek N., (2011): Use of the International Classification of Functioning, Disability and Health (ICF) as a conceptual framework and common language for disability statistics and health information systems. BMC Public Health, 11(3):1186.

Leonardi M., Raggi A., Quintas R. and Cerniauskaite M., (2013): ICF implementation in Poland and Egypt, Beijing, China: WHO -family of international classifications network annual meeting. [Online] Available at: https://www.who.int. [Accessed 16th April 2016].

María D., Begoña O., and Alejandro S., (2016): A review of chronic pain impact on patients, their social environment and the health care system. Journal of Pain Research, 9: 457-467.

Martino V. and Chappell D., (2006): Violence at work. 3rd ed. International Labor Organization (ILO), Geneva.117-215.

Nelson D., Sosin D., Sacks J., (1989): Head injuryassociated deaths in the United States from 1979 to 1986. Journal of the American Medical Association, 12 (6):791.

Nicholas B., (2016): Forensic autopsy of blunt force trauma. American Academy of Forensic Sciences. [Online] Available at: https://www.emedicine.medscape.com.

[Accessed $16^{\text {th }}$ October 2018].

Nolo (2018): Understanding the Permanent Disability Rating System. [Online] Available at: https:// www.disabilitysecrets.com. [Accessed 16th October 2018].

Shalabi R., Al Amr Y. and khoujah E., (2006): Vascular injuries of the upper extremity. Journal Vascular Brasileiro, 5(4):271-276.

Shokry D., (2016): Methods of Ascertainment of personal damage in Egypt. Cited In: Personal Injury and Damage Ascertainment under Civil Law: State-of-the-Art International Guidelines by Ferrara D. Springer, Cham,321-334.

Simon L., Lopez R., King K., (2019): Blunt force trauma, StatPearls [Online] Available at: https://www.ncbi.nlm.nih.gov [Accessed 16th February 2020].

State Information Service (SIS, 2017): Care for people with disabilities. [Online] Available at Available at: http://www.sis.gov.eg. [Accessed 16th October 2016].

Takala J., Hämäläinen P. and Saarela K., (2007): Global estimates of fatal work-related diseases. American Journal of Industrial Medicine. 50(1):28-41.

United Nations (UN, 2015): Ageing and disability. UN. [Online] Available at: https://www.un.org. [Accessed 16th June 2018].

Vandervelde L., Van den Bergh PY., Goemans N. and Thonnard J., (2007): Activity limitations in patients with neuromuscular disorders: a responsiveness study of the ACTIVLIM questionnaire. Neuromuscular Disorder Journal, 19(2):99-103.

Wasfy I., Wasfy E., Aly T. and Abd-Elsayed A., (2009): Ophthalmic medicolegal cases in Upper Egypt. International Archives of Medicine, 2(1): 1-6.

Whiteneck G., Cuthbert j., Corrigan J. and Bogner J., (2016): Prevalence of Self-Reported lifetime history of traumatic brain injury and associated disability: A Statewide Population-Based Survey. Journal of Head trauma Rehabilitation, 1: 5-62.

World Health Organization (WHO, 2009): Health statistics and information systems. [Online] Available at: https://www.who.int/ [Accessed 16th January 2018].

World Health Organization (WHO, 2011): World Report on Disability. [Online] Available at: https://www.who.int/ [Accessed $16^{\text {th }}$ January 2018].

World Health Organization (WHO, 2015): Disability and health factsheets. [Online] Available at: http://www.who.int/ [Accessed 16th January 2018].

Zanaty A. (2005): A prospective study of some medicolegal aspects of physical and sexual family violence cases at Menoufia University. 


\section{العاهة المستديمة بين المنظومة الطبية الثرعية القائمة والواقع

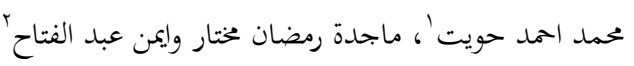

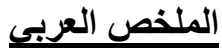

المقدمة: العاهة المستديمة هي فقد العضو أو منفعته أو وظيفته مما يؤدى الى عدم القدرة على الإخراط في أي عمل أو نشاط ويوجد أكثر من

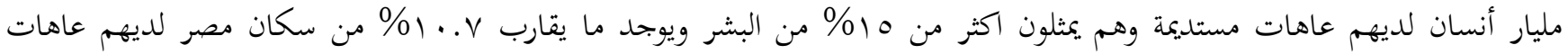

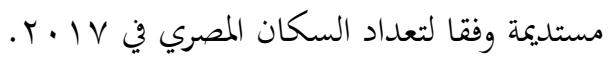

هدف هذه الدراسة: هو تقيم صلاحية وفعالية جداول العاهة المستديمة المصرية المرفقة بالقانون والمستخدمة في تحديد نسبه العاهة المستديمة والمقارنة بينها وبين التصنيف الدولي التصنيف الدولي للأداء والإعاقة والصحة

طريقة البحث: تم ذلك من خلال فحص ملفات كل الحالات من ذوى الإعاقات التي عرضت على مصلحة الطب الشرعي بالمنوفية لتقييم

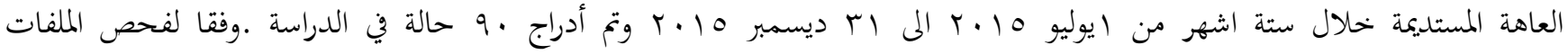
والمعلومات تم تصميم نموذج لتقييم العاهة المستديمة ثم تم عمل تقييم أخر للحالات بواسطة التصنيف الدولي للأداء والإعاقة والصحة. النتائج: تم أجراء التحليل الإحصائي للبيانات وتم استبعاد ه • ب حالة من اصل 90 ب حالة وذلك لعدم اعتبار إصاباتم كعاهات مستديمة

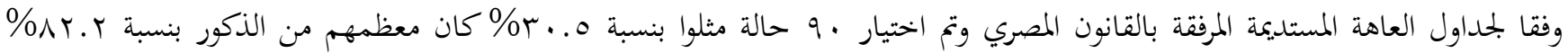

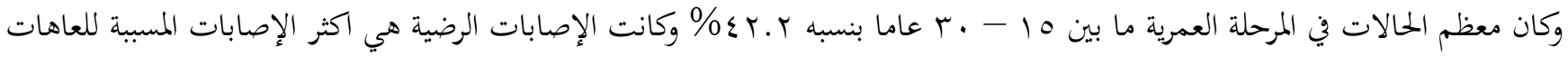

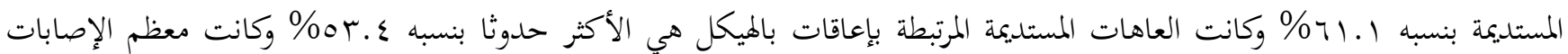

لأسباب غير مرتبطة بالعمل بنسبة ؟.ب9\% معظمهم كان نتيجة للعنف بنسبه ایر\% ولم يتواجد أي عاهات مستديمة نتيجة للانتحار الخلاصة: وتخلص نتائج هذه الدراسة الى أن الجحاول المستخدمة لتحديد نسببه العاهة المستديمة المرفقة بالقانون بحاجه الى التحديث وإدراج العاهات التي لم تتواجد من قبل كتشوهات الجلد التوصيات: استخدام التصنيف الدولي للأداء والإعاقة والصحة كأداة لتقييم العاهة المستديمة يضمن أن يحصل الشخص على تعويض مناسب واننا بحاجه المى إجراء دراسة موسعه تشمل كل المحافظات والهيئات للتوعية بخطر العاهة المستديمة والحاجه الملحة لتلبية التصنيف الدولي للأداء والإعاقة والصحة كأداة لتقيم نسبة العاهة المستديمة

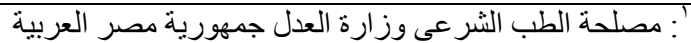

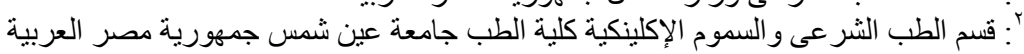

